University of Nebraska - Lincoln

DigitalCommons@University of Nebraska - Lincoln

Effect of Stocking Biomass on Solids, Phytoplankton

Communities, Common Off-Flavors, and Production Parameters in a Channel Catfish Biofloc Technology Production System

\author{
Bartholomew W. Green \\ bart.green@usda.gov \\ Kevin K. Schrader \\ USDA, Agricultural Research Service \\ Peter W. Perschbacher \\ University of Arkansas at Pine Bluff
}

Follow this and additional works at: https://digitalcommons.unl.edu/usdaarsfacpub

Part of the Agriculture Commons, and the Aquaculture and Fisheries Commons

Green, Bartholomew W.; Schrader, Kevin K.; and Perschbacher, Peter W., "Effect of Stocking Biomass on Solids, Phytoplankton Communities, Common Off-Flavors, and Production Parameters in a Channel Catfish Biofloc Technology Production System" (2014). Publications from USDA-ARS / UNL Faculty. 2467. https://digitalcommons.unl.edu/usdaarsfacpub/2467

This Article is brought to you for free and open access by the U.S. Department of Agriculture: Agricultural Research Service, Lincoln, Nebraska at DigitalCommons@University of Nebraska - Lincoln. It has been accepted for inclusion in Publications from USDA-ARS / UNL Faculty by an authorized administrator of DigitalCommons@University of Nebraska - Lincoln. 


\title{
Effect of stocking biomass on solids, phytoplankton communities, common off-flavors, and production parameters in a channel catfish biofloc technology production system
}

\author{
Bartholomew W Green ${ }^{1}$, Kevin K Schrader ${ }^{2}$ \& Peter W Perschbacher $^{3}$ \\ ${ }^{1}$ US Department of Agriculture, Agricultural Research Service, Harry K. Dupree Stuttgart National Aquaculture \\ Research Center, Stuttgart, AR, USA \\ ${ }^{2}$ US Department of Agriculture, Agricultural Research Service, Natural Products Utilization Research Unit, Thad \\ Cochran National Center for Natural Products Research, University, MS, USA \\ ${ }^{3}$ Aquaculture/Fisheries Center, University of Arkansas at Pine Bluff, Pine Bluff, AR, USA
}

Correspondence: B. W. Green, US Department of Agriculture, Agricultural Research Service, Harry K. Dupree Stuttgart National Aquaculture Research Center, Stuttgart, AR, USA. E-mail: Bart.Green@ars.usda.gov

\begin{abstract}
The effect of initial channel catfish (Ictalurus punctatus, Rafinesque, 1818) fingerling biomass $(1.4,1.8$, or $2.3 \mathrm{~kg} \mathrm{~m}^{-3}$ ) on phytoplankton communities, common off-flavours and stocker catfish production parameters was evaluated in biofloc technology production tanks. Stocker catfish size (145.5-172.6 $\mathrm{g} \mathrm{fish}^{-1}$ ) at harvest did not differ among treatments, but net yield increased linearly as initial biomass increased $\left(R^{2}=0.633\right)$. Mean total feed consumption increased linearly with initial catfish biomass $\left(R^{2}=0.656\right)$ and ranged from 10.7 to $15.8 \mathrm{~kg}$ $\mathrm{m}^{-3}$. Total suspended solids (TSS) in all treatments increased linearly with total feed addition, and high TSS appeared to impact negatively daily feed consumption. Initial phytoplankton populations were dominated by small colonial green algae and diatoms, and later transitioned to populations dominated by a small, filamentous cyanobacteria and diatoms. Low, variable concentrations of 2-methylisoborneol and geosmin were present in biofloc tank water during most of the study and two tanks yielded catfish with 2-methylisoborneol or geosmin concentrations that might be classified as off-flavour. One isolate of actinomycete was isolated sporadically from some biofloc tanks, but its abundance was not correlated with 2-methylisoborneol concentration in tank waters. The microbial sources of 2-methylisoborneol and geosmin in biofloc tanks remain unidentified.
\end{abstract}

Keywords: Biofloc technology, stocker channel catfish, off-flavor, phytoplankton, geosmin, 2-methylisoborneol

\section{Introduction}

Channel catfish (Ictalurus punctatus, Rafinesque, 1818) in the south-eastern United States typically are grown from fingerling to market size in earthen ponds managed for multiple-batch culture to facilitate year-round availability of fish for processing. However, as demand by processing plants for larger fish increased, farmers began to re-evaluate single-batch culture, which was the pond management practice used until the mid1970s. A three-phase production system that incorporated a fingerling to stocker production phase along with single-batch stocker to market size production was demonstrated to be feasible and economically viable (D’Abramo, Steeby, Hanson \& Gerard 2006; D’Abramo, Hanson \& Steeby 2008). The yield of catfish falling within the 0.57$2.04 \mathrm{~kg} \mathrm{fish}^{-1}$ size range preferred by processing plants increased to as high as $98.5 \%$ when ponds are stocked with stocker catfish for single-batch culture (Green \& Engle 2004). Although the US Department of Agriculture definition of stocker catfish $\left(28\right.$ - $\left.341 \mathrm{~g} \mathrm{fish}^{-1}\right)$ encompasses a broad size range because it is dependent upon National Agricultural Statistics Services data collection protocols [United States Department of Agriculture 
(USDA) 2010], stocker catfish generally are considered by farmers to be fish that range in size from 114 to $151 \mathrm{~g} \mathrm{fish}^{-1}$. Only a few published studies report on the fingerling to stocker production phase (Pomerleau \& Engle 2003, 2005; D'Abramo et al. 2006, 2008). It should be noted that in $2009,56.6 \%$ of fish stocked into catfish production ponds were stocker catfish (USDA 2010).

Biofloc technology (BFT), or mixed suspendedgrowth, production systems are being used increasingly worldwide for culturing various aquatic animals because of the high yields that are possible. Channel catfish have been grown successfully and net yield of large (>550 $\left.\mathrm{g} \mathrm{fish}^{-1}\right)$ fish was as high as $9.3 \mathrm{~kg} \mathrm{~m}^{-3}$ (Green 2010; Schrader, Green \& Perschbacher 2011). However, there are no reports of rearing channel catfish fingerlings to stocker size in a BFT production system.

In the BFT production system, a complex of living organisms is closely associated with particulate organic matter and is maintained in suspension by continuous aeration. Phytoplankton and bacteria, which are part of this complex of living organisms, metabolize nitrogenous waste excreted by the intensively fed culture animal. Although phytoplankton will be present in BFT production systems exposed to sunlight, only three studies report on phytoplankton community composition. Phytoplankton communities were dominated by green algae (chlorophytes), diatoms (bacillariophytes) and cyanobacteria (cyanophytes) in a freshwater BFT production system used to rear channel catfish (Schrader et al. 2011), or by chlorophytes and cyanobacteria in a brackishwater (Ray, Seaborn, Leffler, Wilde, Lawson \& Browdy 2010) or marine (Vinatea, Galvez, Browdy, Stokes, Venero, Haveman, Lewis, Lawson, Shuler \& Leffler 2010) BFT production system used to grow Litopenaeus vannamei (Boone). However, as phytoplankton populations in catfish production ponds are variable in number and composition during summer months (Tucker \& Lloyd 1984; Tucker \& van der Ploeg 1993; Green, Perschbacher, Ludwig \& Duke 2010) and only one study has evaluated phytoplankton in a freshwater BFT system, further investigation of phytoplankton community dynamics in a catfish BFT production system is warranted.

Among the problems associated with dense, bloom-forming phytoplankton communities in aquaculture ponds is the production of the cyanobacterial 'musty' and 'earthy' off-flavour metabo- lites 2-methylisoborneol (MIB) and geosmin, respectively; these off-flavour compounds accumulate in fish flesh and render them temporarily unmarketable, which has significant economic impact (Smith 1988; Paerl \& Tucker 1995). The annual cost to catfish producers of episodes of off-flavour is estimated at US \$10-60 million annually (Tucker 2000). Geosmin and MIB were detected in a catfish BFT production system and a positive correlation between cumulative feed addition and MIB concentration in tank water indicated the potential for MIB-related off-flavour at high feed application rates (Schrader et al. 2011). Further research on the catfish BFT production system is needed to investigate the relationship between feed application rates and common offflavour problems, and to determine the microbial sources of MIB and geosmin.

The objectives of this study were to determine the effect of initial fish biomass on rearing fingerling channel catfish to stocker size, water quality, phytoplankton dynamics and off-flavour in a BFT production system. Attempts also were made to isolate and identify the microbial sources of MIB and geosmin in the BFT production systems.

\section{Materials and methods}

\section{Biofloc technology production system}

A completely randomized design was used for this study, which was carried out in nine woodframed rectangular tanks with a slightly sloped bottom $\left(18.6 \mathrm{~m}^{2}\right.$, mean $15.6 \mathrm{~m}^{3}$ of water, mean depth of $0.81 \mathrm{~m}$ ) lined with high density polyethylene (HDPE) located outdoors at the USDA Agricultural Research Service, Harry K. Dupree Stuttgart National Aquaculture Research Center (HKDSNARC), Stuttgart, AR, USA. Triplicate tanks were assigned to initial fish biomasses of $1.4,1.8$ or $2.3 \mathrm{~kg} \mathrm{~m}^{-3}\left(26,35\right.$ or 44 fish $\mathrm{m}^{-2}$; 31.4 , 41.3 or 52.3 fish $\mathrm{m}^{-3}$; designated LO, MED, HI respectively). Animal care and experimental protocols were approved by the HKDSNARC Institutional Animal Care and Use Committee and conformed to ARS Policies and Procedures 130.4 and 635.1.

One $1.865-\mathrm{kW}$ blower per 3 tanks provided air continuously through a diffuser grid $\left(\begin{array}{l}6 \\ 5.95 \mathrm{~m}\end{array}\right.$ $\times 2.5 \mathrm{~cm}$ polyvinyl chloride pipes with $1.9-\mathrm{mm}$ diameter holes drilled at $15-\mathrm{cm}$ intervals) on the bottom of each tank. Between 7 April 2011 and 
15 April 2011, tanks were filled with well water (total alkalinity $=228.4 \mathrm{mg} \mathrm{L}^{-1}$ as $\mathrm{CaCO}_{3}$ ), and each was seeded with $2.3 \mathrm{~m}^{3}$ of water from a SNARC pond containing a phytoplankton bloom, fertilized with $0.93 \mathrm{~kg}$ 11-37-0 (N-P-K) and $1.5 \mathrm{~kg}$ dried molasses (Sweet45; Westway Feed Products, New Orleans, LA, USA), and treated with $4.5 \mathrm{~kg}$ stock salt to ensure that chloride concentration exceeded $100 \mathrm{mg} \mathrm{L}^{-1}$. An additional $1.1 \mathrm{~kg}$ dried molasses was added to each tank from 29 April to 11 May. Pond water was added to the tanks to expedite development of a phytoplankton bloom to aid in the removal of total ammonia-N (TAN). Dried molasses was added to tanks as a carbon source to stimulate bacterial transformation of TAN (Avnimelech, Diab, Kochba \& Mokady 1992; Avnimelech 1999). No water was exchanged, but well water was added as needed to replace evaporative loss. Sodium bicarbonate $\left(1.13 \mathrm{~kg} \mathrm{tank}^{-1}\right.$ ) was added as needed to maintain $\mathrm{pH}$ above $\mathrm{pH}$ 7.0; mean total sodium bicarbonate added was 9.6, 13.5 and $15.6 \mathrm{~kg}$ $\operatorname{tank}^{-1}$ for the LO, MED and HI treatments respectively.

\section{Catfish stocking and feeding rates}

Fingerling channel catfish $\left(\right.$ mean $=48 \mathrm{~g} \mathrm{fish}^{-1}$ ) were stocked into tanks on 19 April 2011. Nearly $50 \%$ of the fish stocked in one MED treatment replicate tank perished during an outbreak of Ichthyophthirius multifilis that occurred from 31 May-3 June. Consequently, this replicate was excluded from the experiment. Fish were fed once daily between 1000 and $1400 \mathrm{~h}$ with a commercially produced $32 \%$ protein floating extruded feed to apparent satiation (10 $\mathrm{min})$ and the amount was recorded. Feed conversion ratio (FCR) was calculated for each tank as the total quantity of administered feed divided by the sum of the net total yield. The weight of dead fish recovered was recorded. All tanks were harvested by draining; one replicate tank per treatment was harvested on 19 October and the remaining two replicates per treatment were harvested on 20 October. At harvest, at least 100 fish per tank were weighed individually and the remaining fish were counted and weighed in bulk.

Solids concentrations (total suspended and settleable) in tanks intentionally were not managed during this experiment to evaluate the maximum concentrations and if fish were impacted. Over a 4-day period beginning 26 September (18-21 day before harvest), 63 fish died $\left(125 \pm 55 \mathrm{~g} \mathrm{fish}^{-1}\right.$, $\pm \mathrm{SD})$ in one HI treatment tank; necropsy of several fish revealed no definitive cause of death. Mortality appeared to affect the fish population uniformly based on the average weight (121 \pm $56 \mathrm{~g} \mathrm{fish}^{-1}$ ) at harvest. The biomass of dead fish from this tank was included in the tank gross and net yields for statistical analysis; tank survival was based on fish harvested. On 26 and 27 September, $0.5 \mathrm{~m}^{3}$ of water was discharged from this HI treatment tank and the tank was re-filled with well water. As water quality changed dramatically because of the water exchange, only data prior to 26 September from this tank were used in the data analysis.

\section{Water quality analyses}

Dissolved oxygen and temperature in each tank were monitored continuously (10-s scan rate) using a galvanic oxygen sensor (Type III; Oxyguard, Birkerød, Denmark) and a thermister (Model 109; Campbell Scientific, Logan, UT, USA) connected to a datalogger (Model CR206 or CR1000; Campbell Scientific).

Water samples were collected weekly from each tank. Sample $\mathrm{pH}$ was measured electrometrically. Total alkalinity (titration), settleable solids (SS), total suspended solids (TSS) and total volatile solids (TVS) in raw samples were measured using methods given by Eaton, Clesceri, Rice and Greenberg (2005). Water was filtered through 0.2- $\mu \mathrm{m}$ pore size membrane filter and analysed for nitritenitrogen $\left(\mathrm{NO}_{2}-\mathrm{N}\right.$, diazotization), nitrate-nitrogen $\left(\mathrm{NO}_{3}-\mathrm{N}\right.$, cadmium reduction) and soluble reactive phosphorus ( $\mathrm{PO}_{4}-\mathrm{P}$, ascorbic acid method) using flow injection analysis according to manufacturer instructions (FIAlab 2500; FIAlab Instruments, Bellevue, WA, USA). Flow injection analysis also was used to quantify total ammonia-nitrogen (TAN) fluorometrically in filtered samples using the $o$-phthaldialdehyde method of Genfa and Dasgupta (1989). Water samples were filtered through a $0.45-\mu \mathrm{m}$ pore size glass fibre filter for chlorophyll $a$ analysis. Chlorophyll $a$ was extracted in 2:1 chloroform:methanol from the phytoplankton (planktonic algae and cyanobacteria as well as those associated with the biofloc) retained on the filter, and the chlorophyll $a$ concentration in the extract was determined using spectroscopy (Lloyd \& Tucker 1988). 


\section{Phytoplankton identification and enumeration}

Water samples for phytoplankton identification and enumeration were collected from tanks biweekly beginning on 19 April, and preserved with formalin until microscopic examination could be performed. Identification and enumeration was accomplished using a Sedgewick-Rafter counting cell and a phase contrast microscope $(150 \times$ magnification) equipped with a Whipple grid in the ocular lens. Natural units (single cells, colonies and filaments or trichomes) were counted in five grid quadrants (fields) chosen at random across the counting chamber. Algae and cyanobacteria were identified to genus, with two exceptions as follows: (1) cyanobacteria commonly responsible for noxious algal blooms (Paerl \& Tucker 1995) were identified to species based on Cocke (1967) with additional reference to Desikachary (1959); and (2) Bacillariophyta were designated to one of two orders [Centrales (centric) or Pennales (pennate) diatoms] as appropriate. Current taxonomic names [http://www.algaebase.org/ (accessed April 2012)] of phytoplankton were used. Phytoplankton abundance was reported as natural units per millilitre.

\section{Determination of MIB and geosmin levels}

Beginning 6 June and continuing at monthly intervals through 11 October and on 18 October, a water sample was collected from each tank for analysis of 2-methylisoborneol and geosmin. Individually labelled 20-mL glass scintillation vials were filled completely with sampled water and stored at $4^{\circ} \mathrm{C}$ until overnight shipment to the USDA-ARS Natural Products Utilization Research Unit (NPURU) for analysis.

At the end of the study, five catfish were selected at random from each tank, euthanized by cranial percussion and filleted. Catfish fillets (one fillet fish $^{-1}$ ) were placed in individual plastic bags, vacuum sealed and immediately frozen until overnight shipment to the USDA-ARS-NPURU for analysis. Fish fillets were stored frozen until further processing to obtain microwave distillates. For analysis of each fillet, a single 20 -g sample was resected from the anterior end of the fillet by cutting $1-\mathrm{cm}$ wide portions (2-3 portions per fillet) vertically from the dorsal to ventral side of the fillet and then each 1-cm wide sample was cut into approximately $1-\mathrm{cm}$ cube-like pieces to undergo microwave distillation according to the method of Lloyd and Grimm (1999).

Prior to analysis, water samples and microwave distillates of catfish fillet samples were processed by placing $0.6-\mathrm{mL}$ aliquots into separate 2-mL glass crimp-top vials and adding $0.3 \mathrm{~g}$ sodium chloride to each vial. The methodology of Lloyd, Lea, Zimba and Grimm (1998) as modified by Schrader, Nanayakkara, Tucker, Rimando, Ganzera and Schaneberg (2003) were used to quantify MIB and geosmin using solid phase microextraction and gas chromatography-mass spectrometry (SPME-GC-MS). Samples were analysed using an Agilent 6890 gas chromatograph (Agilent, Palo Alto, CA, USA) and Agilent 5973 mass selective detector with attached CombiPal autosampler and solid phase microextraction assembly (LEAP Technologies, Carrboro, NC, USA). The GC-MS conditions were the same as those outlined by Schrader, Davidson, Rimando and Summerfelt (2010) and each sample was run in triplicate. The instrumental detection limit for each compound was 1 part per trillion.

\section{Isolation of actinomycetes}

The water samples collected for MIB and geosmin analysis also were used in attempts to isolate MIB-producing and geosmin-producing actinomycetes. Water samples containing biofloc were serially diluted $(1: 10)$ in sterile saline $(0.85 \%)$ water. Diluted biofloc samples $\left(10^{4}, 10^{5}\right.$ and $10^{6}$ dilutions $)$ were used to inoculate $1 \%$ yeast extract- $1 \%$ dextrose (YD) agar ( $\mathrm{pH}$ 7.5) plates and actinomycete isolation agar (AI) (Bacto; Becton, Dickinson and Co., Franklin Lakes, NJ, USA) plates using the spread-plate technique. Inoculated plates were incubated for $7-10$ days at $29^{\circ} \mathrm{C}$. Colonies bearing resemblance to actinomycete colony morphology (e.g. chalky appearance, 'biting' into the agar surface) were streaked for isolation onto the same type of agar on which they originally grew. Presumptive identification and designation of actinomycetes into suprageneric groups was made based on colony morphology and pigment production. Colonies of actinomycete isolates producing earthy or musty odours were aseptically removed from the agar surface and transferred to a 2-mL glass crimp-top vial containing $0.6 \mathrm{~mL}$ of ultrapure water and $0.3 \mathrm{~g}$ of sodium chloride for analysis using SPMEGC-MS to confirm geosmin and/or MIB production by the actinomycete isolate. Genotypic identification 
of confirmed odour-producing isolates was performed by phylogenetic analysis (Accugenix, Newark, DE, USA) using comparative $16 \mathrm{~S}$ rRNA gene sequencing (500 bp). Genomic DNA of isolates was extracted, purified and target DNA (portion of $16 \mathrm{~S}$ ribosomal gene) amplified using polymerase chain reaction $(\mathrm{PCR})$ with the bacterial primers 531R (5'- TAC CGC GGC TGC TGG CAC -3') and 005F (5'- TGG AGA GTT TGA TCC TGG CTC AG $\left.3^{\prime}\right)$. Each PCR product was purified and sequenced using dye-terminator sequencing chemistry to fluorescently label each nucleotide of the PCR product. Fluorescently labelled product was analysed on an automated fluorescent DNA sequencer to provide an electropherogram and sequence the sample. Finally, each generated sequence was compared with the Accugenix, database. For each isolate sample, a phylogenetic tree was generated using neighbour joining and closest match methods, and final identification was made based on genetic per cent difference (distance measurement) and the phylogenetic tree.

\section{Data analysis}

Datasets were analysed using the mixed models (MIXED) and generalized linear mixed models (GLIMMIX) procedures of SAS version 9.2 (SAS Institute, Cary, NC, USA). Fillet off-flavour data were normalized using the Box-Cox transformation before analysis (Box \& Cox 1964). The relationship between weekly means of daily feed ration and TSS in tanks from May through August was analysed using piecewise regression (Ryan \& Porth 2007). Differences were considered to be significant $\alpha=0.05$.

Total phytoplankton number and chlorophyll $a$ data were analysed for the entire experiment and by period because we observed two shifts in community structure and total numbers during the course of the experiment. In the latter data analyses, a dummy variable (period) was defined to identify the three periods; dates encompassed by each period were 19 April-1 June (period 1), 2 June-26 July (period 2) and 27 July-18 October (period 3). Total phytoplankton count data were log-transformed for data analysis because of the high variability among individual data points and to ensure that the residuals met the assumptions of the analysis; the constant 1 was added to each data point before logtransformation to ensure the transformation was defined. Data for individual phytoplankton groups (cyanobacteria colonies, cyanobacteria trichomes, etc.) were not analysed among periods because the data were not distributed normally and we were unable to identify an appropriate probability distribution to allow convergence in GLIMMIX. Individual phytoplankton group (e.g. cyanobacteria trichomes) abundance and TSS and SS data for the entire culture period were analysed using the Spearman rank-order correlation procedure (CORR); the analysis was repeated for dates when MIB and geosmin concentrations in water data were available.

\section{Results}

\section{Fish production and feed consumption}

Stocker-size channel catfish were harvested from all treatments. Individual weight, net yield, net daily yield, survival and FCR did not differ significantly among treatments, whereas gross yield did differ significantly (Table 1). Net yield increased linearly as initial biomass increased $\left(R^{2}=0.633\right.$, $P=0.018)$. Overall mean survival was $95.0 \%$ and FCR was 3.2.

High feed consumption was sustained during the period from 7 July through 26 September. Mean daily feed consumption during the peak feeding period increased linearly with increased initial biomass $\left(R^{2}=0.567, P=0.031\right)$; treatment means were 86.9, 111.7 and $132.1 \mathrm{~g} \mathrm{~m}^{-3} \mathrm{~d}^{-1}$ for the LO, MED and HI treatments respectively. Corresponding maximum daily feed consumption averaged 131.7, 160.8 and $189.4 \mathrm{~g} \mathrm{~m}^{-3}$ respectively. Mean total feed consumption $(y)$ was 10.7, 13.2 and 15.8 $\mathrm{kg} \mathrm{m}^{-3}$ for the LO, MED and HI treatments, respectively, and was linearly related to initial biomass $(x)$ $\left(y=3.2+5.0 x, \quad R^{2}=0.656, \quad P=0.015\right)$. Mean daily feed consumption $(y)$ for the entire experiment averaged 59.0, 72.5 and $86.5 \mathrm{~g} \mathrm{~m}^{-3} \mathrm{~d}^{-1}$ for the LO, MED and HI treatments, respectively, and increased linearly with initial biomass $(x)$ $\left(y=16.7+30.5 x, R^{2}=0.655, P=0.015\right)$.

\section{Water quality}

Mean weekly water temperature ranged from 16.7 to $32.2^{\circ} \mathrm{C}$ over the course of the experiment and averaged $( \pm \mathrm{SD}) 26.3 \pm 4.8^{\circ} \mathrm{C}$. Tank mean DO concentrations did not differ significantly among treatments and averaged $( \pm \mathrm{SD}) 87.0 \pm 11.2 \%$ of saturation. 
Table 1 Least squares means $( \pm \mathrm{SE})$ for individual weight at harvest, gross and net yields, net daily yield, survival, and feed conversion ratio (FCR) for channel catfish stocked at $1.4-2.3 \mathrm{~kg} \mathrm{~m}^{-3}$ in a biofloc technology production system in tanks

\begin{tabular}{|c|c|c|c|c|c|c|}
\hline \multirow{2}{*}{$\begin{array}{l}\text { Initial biomass } \\
\left(\mathrm{kg} \mathrm{m}^{-3}\right)^{\star}\end{array}$} & \multirow{2}{*}{$\begin{array}{l}\text { Individual weight } \\
\left(\mathrm{g} \text { fish }^{-1}\right)\end{array}$} & \multicolumn{2}{|c|}{ Yield $\left(\mathrm{kg} \mathrm{m}^{-3}\right)$} & \multirow{2}{*}{$\begin{array}{l}\text { Net daily yield } \\
\left(\mathrm{g} \mathrm{m}^{-3} \mathrm{~d}^{-1}\right)\end{array}$} & \multirow[b]{2}{*}{ Survival (\%) } & \multirow[b]{2}{*}{ FCR } \\
\hline & & Gross & Net & & & \\
\hline 1.4 & $172.6 \pm 8.4$ & $4.9 \pm 0.3^{b}$ & $3.5 \pm 0.3$ & $19.1 \pm 1.7$ & $95.3 \pm 0.2$ & $3.1 \pm 0.4$ \\
\hline 1.8 & $150.8 \pm 10.3$ & $5.9 \pm 0.4^{\mathrm{ab}}$ & $4.1 \pm 0.4$ & $22.3 \pm 2.0$ & $95.5 \pm 0.3$ & $3.2 \pm 0.5$ \\
\hline 2.3 & $145.5 \pm 8.4$ & $7.1 \pm 0.3^{\mathrm{a}}$ & $4.8 \pm 0.3$ & $26.0 \pm 1.7$ & $94.5 \pm 0.2$ & $3.4 \pm 0.4$ \\
\hline ANova, $P>\mathrm{F}$ & 0.149 & 0.010 & 0.082 & 0.082 & 0.939 & 0.862 \\
\hline
\end{tabular}

$*_{n}=3$ for 1.4 and $2.3 \mathrm{~kg} \mathrm{~m}^{-3}$ treatments and $n=2$ for $1.8 \mathrm{~kg} \mathrm{~m}^{-3}$ treatment.

Means within column followed by the same letter are not significantly different.

Table 2 Least squares means $( \pm \mathrm{SE})$ for water quality variables in biofloc technology production tanks stocked with channel catfish at $1.4-2.3 \mathrm{~kg} \mathrm{~m}^{-3}$

\begin{tabular}{|c|c|c|c|c|}
\hline \multirow[b]{2}{*}{ Variable } & \multicolumn{3}{|c|}{ Initial Biomass $\left(\mathrm{kg} \mathrm{m}^{-3}\right)^{*}$} & \multirow[b]{2}{*}{ ANova, $P>\boldsymbol{F}$} \\
\hline & 1.4 & 1.8 & 2.3 & \\
\hline $\mathrm{NH}_{4}-\mathrm{N} \dagger\left(\mathrm{mg} \mathrm{L}^{-1}\right)$ & $0.21 \pm 0.02$ & $0.23 \pm 0.02$ & $0.22 \pm 0.02$ & 0.756 \\
\hline $\mathrm{NO}_{2}-\mathrm{N} \dagger\left(\mathrm{mg} \mathrm{L}^{-1}\right)$ & $0.44 \pm 0.10$ & $0.47 \pm 0.12$ & $0.59 \pm 0.10$ & 0.598 \\
\hline $\mathrm{NO}_{3}-\mathrm{N} \dagger\left(\mathrm{mg} \mathrm{L}^{-1}\right)$ & $62.24 \pm 4.18^{\mathrm{b}}$ & $79.37 \pm 5.12^{\mathrm{ab}}$ & $86.33 \pm 4.18^{\mathrm{a}}$ & 0.024 \\
\hline $\mathrm{PO}_{4}-\mathrm{P} \dagger\left(\mathrm{mg} \mathrm{L}^{-1}\right)$ & $24.88 \pm 1.18^{b}$ & $27.82 \pm 1.44^{\mathrm{ab}}$ & $32.15 \pm 1.18^{a}$ & 0.019 \\
\hline Total Alkalinity ( $\mathrm{mg} \mathrm{L}^{-1}$ as $\mathrm{CaCO}_{3}$ ) & $132.5 \pm 2.4$ & $137.3 \pm 3.0$ & $129.6 \pm 2.4$ & 0.229 \\
\hline $\left.\mathrm{SS} \dagger(\mathrm{mL} \mathrm{L})^{-1}\right)$ & $57 \pm 5$ & $63 \pm 6$ & $58 \pm 5$ & 0.777 \\
\hline $\mathrm{TSS} \dagger\left(\mathrm{mg} \mathrm{L}^{-1}\right)$ & $647.8 \pm 44.5$ & $724.0 \pm 54.5$ & $759.4 \pm 44.5$ & 0.286 \\
\hline TVSS $\dagger\left(\mathrm{mg} \mathrm{L}^{-1}\right)$ & $532.9 \pm 42.9$ & $600.4 \pm 52.6$ & $641.1 \pm 42.9$ & 0.288 \\
\hline TFSS $\uparrow\left(\mathrm{mg} \mathrm{L}^{-1}\right)$ & $115.4 \pm 3.1$ & $124.0 \pm 3.8$ & $120.0 \pm 3.1$ & 0.302 \\
\hline
\end{tabular}

$*_{n}=3$ for 1.4 and $2.3 \mathrm{~kg} \mathrm{~m}^{-3}$ treatments and $n=2$ for $1.8 \mathrm{~kg} \mathrm{~m}^{-3}$ treatment.

$\dagger$ Total ammonia nitrogen $\left(\mathrm{NH}_{4}-\mathrm{N}\right)$, nitrite-nitrogen $\left(\mathrm{NO}_{2}-\mathrm{N}\right)$, nitrate-nitrogen $\left(\mathrm{NO}_{3}-\mathrm{N}\right)$, soluble reactive phosphorus $\left(\mathrm{PO}_{4}-\mathrm{P}\right)$, settleable solids (SS), total suspended solids (TSS), total volatile suspended solids (TVSS), total fixed suspended solids (TFSS).

Means within row followed by the same letter are not significantly different.

Nitrate-nitrogen and soluble reactive phosphorus were the only mean water quality variables that differed significantly among treatments (Table 2). Mean $\mathrm{NO}_{3}-\mathrm{N}$ and $\mathrm{PO}_{4}-\mathrm{P}$ each increased linearly as initial biomass $\left(y=27.1+26.4 x, \quad R^{2}=0.723\right.$, $P=0.007, \quad$ and $y=13.5+8.1 x, \quad R^{2}=0.793$, $P=0.003$ respectively) or total quantity of feed fed $\left(y=29.6+3.5 x, \quad R^{2}=0.575, \quad P=0.029, \quad\right.$ and $y=15.2+1.0 x, \quad R^{2}=0.545, \quad P=0.037$ respectively) increased. Total ammonia nitrogen and $\mathrm{NO}_{2}-\mathrm{N}$ concentrations increased from early May, peaked 17-25 May, and declined by mid-June to below $0.5 \mathrm{mg} \mathrm{NH}_{4}-\mathrm{N} \mathrm{L}^{-1}$ and $1.0 \mathrm{mg} \mathrm{NO}_{2}-\mathrm{N} \mathrm{L}^{-1}$ for the remainder of the experiment. Average maximum concentrations for TAN and $\mathrm{NO}_{2}-\mathrm{N}$ were 0.98-1.45 $\mathrm{mg} \mathrm{NH}_{4}-\mathrm{N} \mathrm{L}^{-1}$ and 3.9-4.8 $\mathrm{mg} \mathrm{NO}_{2}-\mathrm{N}$ $\mathrm{L}^{-1}$ respectively. Nitrate-nitrogen concentration increased throughout the culture period following the onset of nitrification; mean final concentration was $138.7,182.6$ and $198.5 \mathrm{mg} \mathrm{L}^{-1} \mathrm{NO}_{3}-\mathrm{N}$ for the LO, MED and HI treatments respectively. Positive correlations were observed in all treatments between $\mathrm{NO}_{3}-\mathrm{N}$ and each of TSS $(R>0.950$, $P<0.001)$ and SS $(R>0.890, P<0.001)$. Average $\mathrm{pH}$ was $\mathrm{pH} 8.4$ initially, declined as nitrification increased, and ranged from $\mathrm{pH} 7.0$ to 7.5 from early July onwards as a result of sodium bicarbonate applications, which also served to maintain mean total alkalinity above $50 \mathrm{mg} \mathrm{L}^{-1}$ as $\mathrm{CaCO}_{3}$. Total suspended solids and settleable solids concentrations in each treatment were positively correlated $(R>0.94, \quad P<0.001)$. Mean treatment total suspended solids increased over time (Fig. 1), exceeded $500 \mathrm{mg} \mathrm{L}^{-1}$ by day 90 and attained a mean maximum concentration of $1278.0 \mathrm{mg} \mathrm{L}^{-1}, 1525.7 \mathrm{mg} \mathrm{L}^{-1}$ and $1682.6 \mathrm{mg}$ $\mathrm{L}^{-1}$ for the LO, MED and HI treatments respectively. Likewise, mean treatment settleable solids concentration increased throughout the experiment (Fig. 1); mean maximum concentration was 

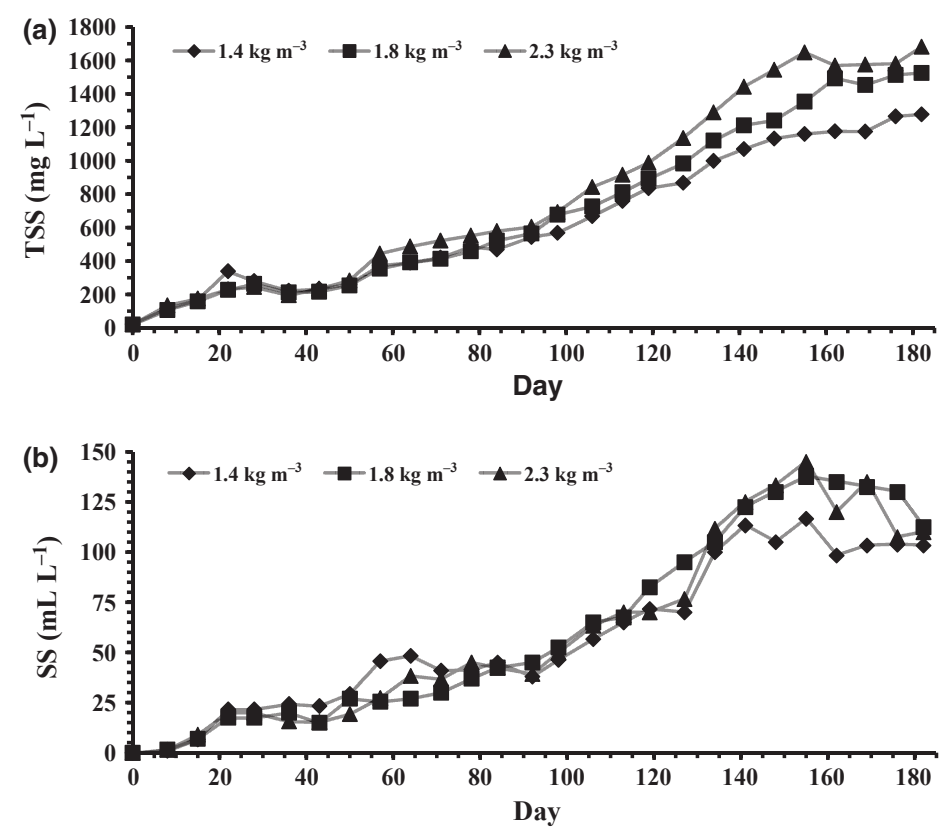

Figure 1 Mean total suspended solids (a) and settleable solids (b) by treatment over time in biofloc technology production tanks stocked with channel catfish at 1.4 $-2.3 \mathrm{~kg} \mathrm{~m}^{-3}$. Note that for clarity, different scales were used for the $y$ axis in each figure.

$117 \mathrm{~mL} \mathrm{~L}^{-1}, 138 \mathrm{~mL} \mathrm{~L}^{-1}$ and $145 \mathrm{~mL} \mathrm{~L}^{-1}$ for the LO, MED and HI treatments respectively. Total suspended solids increased linearly with cumulative feed addition in all treatments (LO: $R^{2}=0.959$, $P<0.0001 ;$ MED: $R^{2}=0.984, \quad P<0.0001 ;$ HI: $\left.R^{2}=0.973, P<0.0001\right)$.

A relationship was observed in all treatments between daily feed consumption and TSS. Weekly means of daily feed consumption increased linearly until TSS concentration ranged from 550 to $850 \mathrm{mg} \mathrm{L}^{-1}$ and then levelled off (Fig. 2). Results of piecewise regression showed that the mean $( \pm \mathrm{SE})$ breakpoint occurred at $563.8 \pm 42.3$, $614.4 \pm 51.9$ and $853.2 \pm 42.3 \mathrm{mg} \mathrm{L}^{-1}$ TSS for the LO, MED and HI treatments respectively. The HI treatment breakpoint was significantly greater than the LO and MED breakpoints, which did not differ.

\section{Phytoplankton and chlorophyll a}

Total phytoplankton (natural units $\mathrm{mL}^{-1}$ ) peaked 2 weeks after the tanks were stocked (period 1), declined to low numbers during period 2 and increased to moderate numbers during period 3 (Fig. 3). Mean total phytoplankton numbers did not differ significantly among the LO, MED and HI treatments, but did differ significantly among periods; the treatment $\times$ period interaction was not significant. Colonial chlorophytes and pennate diatoms predominated in all three treatments during period 1. The colonial green alga Scenedesmus sp. comprised 64\%, 46\% and 52\%, and pennate diatoms comprised $16 \%, 13 \%$ and $19 \%$ of total phytoplankton numbers in the LO, MED and HI treatments, respectively, during period 1 . In addition, the colonial green alga Protococcus sp. comprised $20 \%$ of phytoplankton numbers in the period 1 MED treatment. The filamentous cyanobacteia, Planktothrix (Oscillatoria) agardhii, was present in one HI treatment tank only on the 17 May 11 sampling date and comprised $0.4 \%$ of the phytoplankton population. Another filamentous cyanobacteria, Pseudanabaena sp., was present in 7 of 8 tanks during period 1, usually only on 1-2 sample dates (17 May and 1 June); this genus comprised $0.3-3.7 \%$ of the phytoplankton population on a given sampling date. Cyanobacteria trichomes and colonies, pennate diatoms, and colonial and filamentous chlorophytes were the dominant groups during period 2 in all treatments. The filamentous cyanobacterium Jaaginema subtilissimum comprised $27 \%, 28 \%$ and $42 \%$; pennate diatoms comprised $19 \%, 24 \%$ and $12 \%$; and the colonial cyanobacterium Coelosphaerium sp. comprised $16 \%, 11 \%$ and $6 \%$ of phytoplankton numbers in the LO, MED and HI treatments, respectively, during period 2. Also during period 2, Scenedesmus sp. comprised $21 \%$ and $15 \%$ of phytoplankton numbers in the MED and HI treatments, respectively, and the filamentous green alga Mougeotia sp. comprised $14 \%$ of phytoplankton 

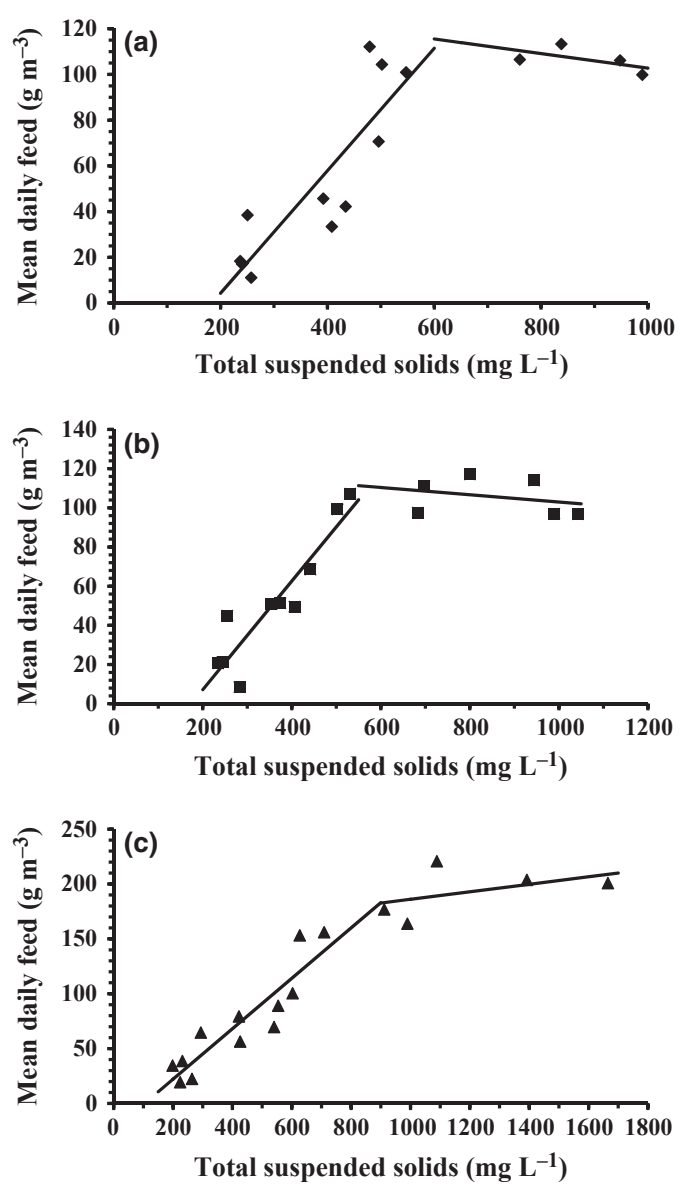

Figure 2 Examples of piecewise regression analysis of mean daily feed versus total suspended solids that show the breakpoint for biofloc technology production tanks stocked with channel catfish. Curves are for one replicate tank each of the 1.4 (a), 1.8 (b) or 2.3 (c) $\mathrm{kg} \mathrm{m}^{-3}$ initial biomass treatments. Note that for clarity, different scales were used for the $y$-axis in each figure.

numbers in the LO treatment. One LO treatment tank contained $P$. agardhii $(7.4 \%$ of total phytoplankton numbers) on the 12 July sampling date and Pseudanabaena sp. (2-3\% of total phytoplankton numbers) on the 15 June and 26 July sampling dates. Pseudanabaena sp. also was present in one $\mathrm{HI}$ treatment tank (3\% of phytoplankton numbers) only on the 15 June sampling date. During period 3, J. subtilissimum comprised $51 \%, 45 \%$ and $46 \%$; pennate diatoms comprised $27 \%, 30 \%$ and $30 \%$; and centric diatoms comprised 14\%, 19\% and 15\% of phytoplankton numbers in the LO, MED and HI treatments respectively.

Phytoplankton populations became less diverse over time. The number of phytoplankton genera in the LO, MED and HI treatments was 22, 24 and 23, respectively, during period $1 ; 12,10$ and 13 , respectively, during period 2 ; and 7,10 and 8 , respectively, during period 3 .

Mean chlorophyll a concentration did not differ significantly among treatments or among periods and the treatment $\mathrm{x}$ period interaction was not significant (Table 3); the grand mean was 1071.9 $\mathrm{mg} \mathrm{m}^{-3}$. Chlorophyll a concentration was not correlated with any variable in a biologically meaningful way.

Significant correlations between phytoplankton groups and between phytoplankton groups and solids were detected within all treatments (Table 4). Of these, several trends were noted. Significant positive correlations between cyanobacteria trichomes and diatoms were observed in the LO and MED treatments. Positive correlations between chlorophytes groups and between euglenoids and chlorophytes groups occurred in all treatments. In all treatments, TSS and SS were positively correlated with cyanobacteria trichomes and diatoms, and negatively correlated with chlorophytes and euglenoids.

\section{MIB and geosmin concentrations}

Concentrations of MIB in tank waters were low, varied among dates and did not exhibit any trends within tank among sample dates (data not shown). With the exception of one sample date (11 October) when MIB concentration spiked to $711 \mathrm{ng} \mathrm{L}^{-1}$ in one LO tank and $107 \mathrm{ng} \mathrm{L}^{-1}$ in one HI tank, concentrations were less than $100 \mathrm{ng} \mathrm{L}^{-1}$. Least squares mean MIB concentration in water was $53.0 \pm 25.0,12.7 \pm 30.7$ and $27.1 \pm 25.0 \mathrm{ng} \mathrm{L}^{-1}$ in the LO, MED and HI treatments, respectively, and did not differ significantly among treatments. Geosmin concentrations in water from tanks varied among dates without trend and generally were low (data not shown). Levels of geosmin were at or below the instrument detection threshold of $1 \mathrm{ng} \mathrm{L^{-1 }}$ in 7 of 8 tanks in the July and August samples. The highest geosmin concentrations were observed in the same LO and HI treatment tanks as for MIB. Geosmin concentration of $170 \mathrm{ng} \mathrm{L}^{-1}$ was measured in the $\mathrm{HI}$ tank on 6 September and of $855 \mathrm{ng} \mathrm{L}^{-1}$ was measured in the LO tank on 11 October. No significant treatment differences were detected for geosmin; least squares means were $64.5 \pm 33.7,5.4 \pm$ 41.3 and $34.1 \pm 33.7 \mathrm{ng} \mathrm{L}^{-1}$ in the LO, MED and $\mathrm{HI}$ treatments respectively. 


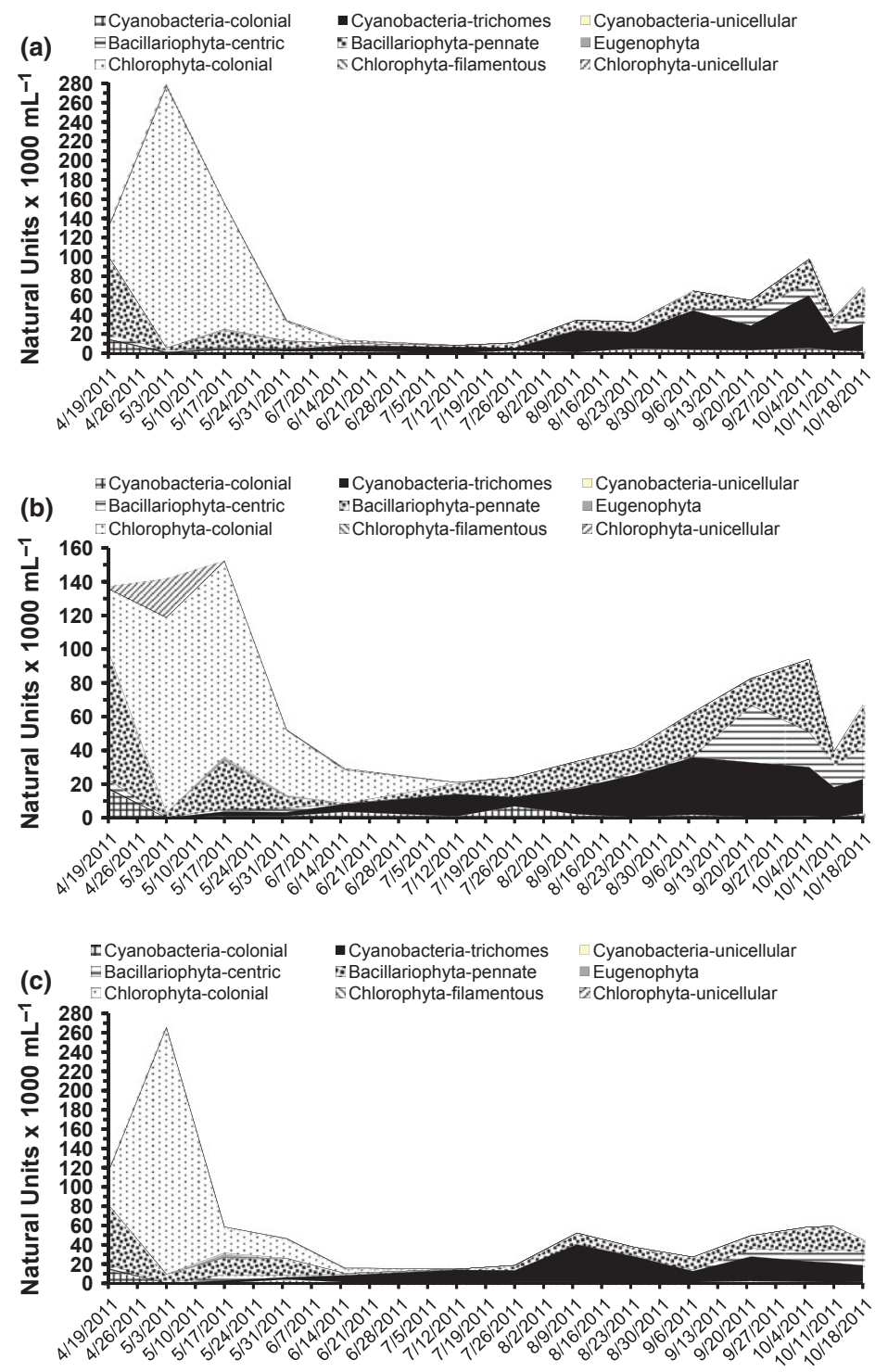

Figure 3 Phytoplankton community composition shown over time by functional group in biofloc technology production system production tanks stocked with channel catfish at initial biomasses of 1.4 (a), 1.8 (b) or 2.3 (c) $\mathrm{kg} \mathrm{m}^{-3}$. Note that for clarity, different scales were used for the $y$-axis in each figure.

Significant positive correlations were detected between MIB and geosmin in the LO ( $\rho=0.535$, $P=0.040)$ and HI $(\rho=0.774, P=0.002)$ treatments. In addition, MIB and TSS were correlated positively in the LO $(\rho=0.546, P=0.035)$ and HI $(\rho=0.699, P=0.008)$ treatments. Chlorophyll $a$ and MIB were correlated positively in the HI ( $\rho=0.560, P=0.046)$ treatment. Centric diatom abundance and MIB were correlated positively in the MED ( $\rho=0.698, P=0.025)$ treatment. Geosmin was correlated positively in the LO treatment with TSS $(\rho=0.771, P<0.001)$, total phytoplankton abundance $(\rho=0.685, \quad P=0.005)$, centric diatoms $(\rho=0.732, P=0.002)$, pennate diatoms $(\rho=0.608, P=0.016)$ and chlorophyll $a$
( $\rho=0.517, P=0.048$ ), and negatively correlated with cumulative feed addition $(\rho=-0.652$, $P=0.010)$. In the HI treatment, geosmin was correlated positively with TSS $(\rho=0.820, P<0.001)$, centric diatoms $(\rho=0.688, P=0.009)$ and colonial cyanobacteria $(\rho=0.652, P=0.016)$.

Concentration of MIB in fillets did not differ significantly among treatments $(P=0.271)$. Transformed treatment least squares means for $\mathrm{MIB}$ were $1.50 \pm 0.07,1.69 \pm 0.09$ and $1.64 \pm 0.07$ $\mathrm{ng} \mathrm{kg}{ }^{-1}$ for LO, MED and HI treatments, respectively; corresponding untransformed data means were $18.53 \pm 2.25, \quad 55.60 \pm 10.12$ and 56.60 $\pm 14.48 \mathrm{ng} \mathrm{kg}^{-1}$ respectively. The highest MIB concentrations were found in fish from one MED 
Table 3 Least squares means $( \pm$ SE) for chlorophyll $a$ and total phytoplankton count in biofloc technology production tanks stocked with channel catfish at $1.4-2.3 \mathrm{~kg} \mathrm{~m}^{-3}$ during period 1 (19 April-1 June), period 2 (2 June-26 July), or period 3 (27 July-18 October)

\begin{tabular}{|c|c|c|c|}
\hline Period & Initial biomass & Chlorophyll $a\left(\mathrm{mg} \mathrm{m}^{-3}\right)$ & Total phytoplankton (natural units $\mathrm{mL}^{-1}$ ) \\
\hline 1 & 1.4 & $1117 \pm 136$ & $112273 \pm 19131$ \\
\hline 1 & 1.8 & $963 \pm 167$ & $102170 \pm 21322$ \\
\hline 1 & 2.3 & $1086 \pm 136$ & $86646 \pm 14764$ \\
\hline 2 & 1.4 & $821 \pm 132$ & $9828 \pm 1964$ \\
\hline 2 & 1.8 & $1022 \pm 161$ & $23329 \pm 5713$ \\
\hline 2 & 2.3 & $1090 \pm 132$ & $15403 \pm 3078$ \\
\hline 3 & 1.4 & $1350 \pm 120$ & $47405 \pm 5792$ \\
\hline 3 & 1.8 & $1142 \pm 146$ & $53028 \pm 7937$ \\
\hline 3 & 2.3 & $886 \pm 124$ & $42799 \pm 5824$ \\
\hline \multicolumn{4}{|l|}{ Main effects means } \\
\hline \multicolumn{4}{|l|}{ Initial biomass } \\
\hline 1.4 & & $1096 \pm 70$ & $37398 \pm 3930$ \\
\hline 1.8 & & $1042 \pm 86$ & $50185 \pm 6458$ \\
\hline 2.3 & & $1020 \pm 71$ & $38514 \pm 4120$ \\
\hline \multicolumn{4}{|l|}{ Period } \\
\hline 1 & & $1055 \pm 85$ & $99797 \pm 10598 a$ \\
\hline 2 & & $977 \pm 82$ & $15229 \pm 1898 c$ \\
\hline 3 & & $1126 \pm 75$ & $47562 \pm 3746 b$ \\
\hline \multicolumn{4}{|l|}{ ANOVA, $P>\mathrm{F}$} \\
\hline Initial biomass & & 0.754 & 0.243 \\
\hline Period & & 0.459 & $<0.0001$ \\
\hline Initial biomass $\times$ period & & 0.141 & 0.176 \\
\hline
\end{tabular}

Means followed by the same letter are not significantly different.

tank (59-94 ng kg${ }^{-1}$ ) (tank R1) and one HI tank (94-182 $\mathrm{ng} \mathrm{kg}^{-1}$ ) (tank R4; see Table 5). No significant differences in fillet geosmin concentrations were detected among treatments $(P=0.334)$. Least squares mean geosmin concentration (transformed data) was $1.74 \pm 0.06,1.62 \pm 0.07$ and $1.76 \pm 0.06 \mathrm{ng} \mathrm{kg}^{-1}$ for the LO, MED and HI treatments, respectively; corresponding raw data means were $123.33 \pm 35.33,29.30 \pm 2.64$ and $85.93 \pm 10.34 \mathrm{ng} \mathrm{kg}^{-1}$ respectively. The highest geosmin concentrations were found in one LO tank (185-465 ng kg ${ }^{-1}$ ) (tank R2) and the one HI tank (101-156 ng kg ${ }^{-1}$ ) (tank R8; see Table 5).

\section{Actinomycetes}

Only one type of actinomycete was isolated from some of the water samples obtained from the BFT tanks (tanks R2, R5, R8 and R9); this isolate was not isolated from each of these tanks during each sampling month. The isolate produced a slight musty odour and was confirmed by SPME-GC-MS to be a 'weak' producer of MIB. Based on colony morphoholgy, this isolate was presumptively identified to be a species of Nocardia. Phylogenetic analysis designated the isolate as Nocardia asteroides. Collectively, there was no correlation of the presence or absence of this isolate in the BFT production tanks with MIB levels in the waters of the respective tanks.

\section{Discussion}

High yields of stocker channel catfish were produced successfully in BFT culture tanks in this study. Although no other published reports on channel catfish stocker production in BFT culture are found, comparison of the present results with pond production of stocker catfish is instructive. Various authors report on production of stocker channel catfish in ponds, but yields should be expressed on a volume basis for comparison to BFT yields. The average commercial catfish production pond depth of $1.37 \mathrm{~m}$ (USDA 2010) was 
Table 4 Spearman rank correlation coefficients, $\rho$, (probability level) for phytoplankton abundance and solids concentrations in biofloc technology production tanks stocked with channel catfish at $1.4 \mathrm{~kg} \mathrm{~m}^{-3}$ (LO Trt), $1.8 \mathrm{~kg} \mathrm{~m}^{-3}$ (MED Trt), or $2.3 \mathrm{~kg} \mathrm{~m}^{-3}$ (HI Trt)

\begin{tabular}{|c|c|c|c|c|c|c|c|c|c|c|c|}
\hline LO Trt & BG-uni & BG-col & BG-tri & D-cen & D-pen & E & G-uni & G-col & G-fil & TSS & ss \\
\hline BG-uni* & 1.000 & $\begin{array}{l}-0.166 \\
(0.312)\end{array}$ & $\begin{array}{c}-0.216 \\
(0.186)\end{array}$ & $-0.029(0.861)$ & $-0.072(0.663)$ & $0.388(0.015)$ & $-0.069(0.677)$ & $0.214(0.191)$ & $-0.075(0.648)$ & $-0.202(0.218)$ & $-0.217(0.185)$ \\
\hline BG-col* & & 1.000 & $\begin{array}{l}0.257 \\
(0.114)\end{array}$ & $0.213(0.192)$ & $0.296(0.067)$ & $-0.134(0.416)$ & $-0.235(0.151)$ & $-0.355(0.027)$ & $-0.121(0.465)$ & $0.390(0.014)$ & $0.431(0.006)$ \\
\hline BG-tri* & & & 1.000 & $0.466(0.003)$ & $0.440(0.005)$ & $-0.572(<0.001)$ & $-0.504(0.001)$ & $-0.762(<0.001)$ & $-0.296(0.067)$ & $0.776(<0.001)$ & $0.755(<0.001)$ \\
\hline D-cen* & & & & 1.000 & $0.553(<0.001)$ & $-0.112(0.497)$ & $-0.060(0.715)$ & $-0.267(0.101)$ & $-0.119(0.470)$ & $0.569(<0.001)$ & $0.508(<0.001)$ \\
\hline D-pen* & & & & & 1.000 & $0.114(0.491)$ & $-0.098(0.553)$ & $-0.376(0.019)$ & $-0.358(0.025)$ & $0.595(<0.001)$ & $0.556(<0.001)$ \\
\hline $\mathrm{E}^{*}$ & & & & & & 1.000 & $0.488(0.002)$ & $0.635(<0.001)$ & $-0.045(0.766)$ & $-0.484(0.002)$ & $-0.524(<0.001)$ \\
\hline G-uni* & & & & & & & 1.000 & $0.648(<0.001)$ & $0.181(0.271)$ & $-0.518(<0.001)$ & $-0.545(<0.001)$ \\
\hline G-col* & & & & & & & & 1.000 & $0.491(0.002)$ & $-0.845(<0.001)$ & $-0.842(<0.001)$ \\
\hline G-fil* & & & & & & & & & 1.000 & $-0.450(0.001)$ & $-0.412(0.009)$ \\
\hline TSS* & & & & & & & & & & 1.000 & $0.948(<0.001)$ \\
\hline SS* & & & & & & & & & & & 1.000 \\
\hline MED Trt & BG-uni & BG-col & BG-tri & D-cen & D-pen & E & G-uni & G-col & G-fil & TSS & ss \\
\hline BG-uni* & 1.000 & $\begin{array}{l}0.161 \\
(0.431)\end{array}$ & $\begin{array}{c}-0.308 \\
(0.126)\end{array}$ & $-0.089(0.666)$ & $-0.305(0.130)$ & $0.296(0.142)$ & $-0.083(0.686)$ & $0.343(0.086)$ & $0.313(0.112)$ & $-0.307(0.127)$ & $-0.290(0.150)$ \\
\hline BG-col* & & 1.000 & $\begin{array}{l}0.144 \\
(0.482)\end{array}$ & $-0.281(0.166)$ & $0.167(0.414)$ & $-0.141(0.491)$ & $-0.406(0.039)$ & $-0.123(0.550)$ & $0.221(0.278)$ & $-0.063(0.759)$ & $-0.059(0.774)$ \\
\hline BG-tri* & & & 1.000 & $0.438(0.025)$ & $0.656(<0.001)$ & $-0.460(0.018)$ & $-0.462(0.017)$ & $-0.777(<0.001)$ & $-0.356(0.075)$ & $0.801(<0.001)$ & $0.820(<0.001)$ \\
\hline D-cen* & & & & 1.000 & $0.322(0.109)$ & $0.159(0.437)$ & $-0.208(0.309)$ & $-0.394(0.047)$ & $-0.064(0.755)$ & $0.635(<0.001)$ & $0.580(0.002)$ \\
\hline D-pen* & & & & & 1.000 & $-0.134(0.514)$ & $-0.367(0.065)$ & $-0.443(0.023)$ & $-0.315(0.116)$ & $0.478(0.014)$ & $0.452(0.021)$ \\
\hline $\mathrm{E}^{*}$ & & & & & & 1.000 & $-0.104(0.613)$ & $0.494(0.010)$ & $0.564(0.003)$ & $-0.373(0.061)$ & $-0.394(0.046)$ \\
\hline G-uni* & & & & & & & 1.000 & $0.379(0.056)$ & $-0.104(0.613)$ & $-0.462(0.017)$ & $-0.463(0.017)$ \\
\hline G-col* & & & & & & & & 1.000 & $0.416(0.035)$ & $-0.844(<0.001)$ & $-0.846(<0.001)$ \\
\hline G-fil* & & & & & & & & & 1.000 & $-0.390(0.049)$ & $-0.340(0.089)$ \\
\hline TSS* & & & & & & & & & & 1.000 & $0.971(<0.001)$ \\
\hline SS* & & & & & & & & & & & 1.000 \\
\hline HI Trt & BG-uni & BG-col & BG-tri & D-cen & D-pen & $E$ & G-uni & G-col & G-fil & TSS & ss \\
\hline BG-uni* & 1.000 & $\begin{array}{l}0.009 \\
(0.960)\end{array}$ & $\begin{array}{l}-0.080 \\
(0.644)\end{array}$ & $0.071(0.680)$ & $-0.227(0.183)$ & $-0.106(0.537)$ & $-0.091(0.599)$ & $0.136(0.431)$ & $0.186(0.276)$ & $-0.113(0.513)$ & $-0.132(0.442)$ \\
\hline BG-col* & & 1.000 & $\begin{array}{l}0.086 \\
(0.617)\end{array}$ & $0.198(0.247)$ & $-0.021(0.904)$ & $-0.378(0.023)$ & $-0.342(0.041)$ & $-0.304(0.072)$ & $0.248(0.144)$ & $0.429(0.009)$ & $0.408(0.014)$ \\
\hline BG-tri* & & & 1.000 & $0.298(0.0 .077)$ & $0.159(0.354)$ & $-0.423(0.010)$ & $-0.453(0.006)$ & $-0.677(<0.001)$ & $-0.374(0.025)$ & $0.684(<0.001)$ & $0.703(<0.001)$ \\
\hline
\end{tabular}


used to estimate reported pond yields on a per cubic meter basis. D’Abramo et al. (2006, 2008) and Pomerleau and Engle (2003, 2005) stocked channel catfish fingerlings $\left(2.5-27 \mathrm{~g} \mathrm{fish}^{-1}\right)$ in earthen ponds at 3.6-10.9 fish $\mathrm{m}^{-3}$ for a $161-$ 210-day stocker production cycle. These authors reported net fish yields that ranged from 0.32 to $0.93 \mathrm{~kg} \mathrm{~m}^{-3}$ and fish sizes at harvest that ranged from 86 to $361 \mathrm{~g} \mathrm{fish}^{-1}\left(\right.$ mean $\left.=165 \mathrm{~g} \mathrm{fish}^{-1}\right)$. Larger fish can be produced in BFT culture when fingerling stocking rates and/or initial size comparable to those reported by D'Abramo et al. (2006, 2008) and Pomerleau and Engle (2003, 2005) are used. Green (2010) reported mean final weights of $473-574 \mathrm{~g} \mathrm{fish}^{-1}$ and net yields of $1.04-3.87 \mathrm{~kg} \mathrm{~m}^{-3}$ for BFT culture tanks stocked at rates and fish sizes within the ranges noted above. In this study, stocking a larger fingerling at much higher stocking rates resulted in stocker catfish with an overall mean weight similar to that of pond-reared stockers. Additional research is needed to determine if further increases in stocking rate increase the yield of stocker-sized catfish.

The high yields of stocker catfish were achieved in this study by high rates of feed application. Mean net yield in the LO treatment was similar to the highest mean net yield reported by Green (2010), yet mean daily (peak) and cumulative feed rates in this study were $80 \%$ and $60 \%$ higher respectively. Both survival and FCR for the Green (2010) treatment were lower $(72.7 \%$ and 1.8 respectively) than the LO treatment. The range of mean daily feed rates (peak) and mean cumulative feed addition in this study overlapped the range reported by Schrader et al. (2011) and exceeded their maximum mean daily (peak) and cumulative feed rates by $31 \%$ and $17 \%$ respectively. However, mean net yield reported by Schrader et al. (2011) generally was higher than those in this study. Survival was high among all treatments in this study and in the Schrader et al. (2011) study. However, FCRs among treatments in this study were double of those obtained in the study by Schrader et al. (2011). It is unlikely that stocker catfish are less efficient feeders based on FCRs of 1.3-1.6 reported for stocker production in ponds with fish survival above 60\% (D'Abramo et al. 2006, 2008). Furthermore, it is unlikely that the high FCRs observed in this study resulted from over-feeding because fish were hand fed to apparent satiation and uneaten feed was not observed on the water surface. One possible explanation is that the high 
Table 5 Mean* $( \pm$ SE) 2-methylisoborneol (MIB) and geosmin levels in catfish fillet samples collected from eight BFT production tanks on 19-20 October 2011

\begin{tabular}{llcc}
\hline $\begin{array}{l}\text { Initial biomass } \\
\left(\mathbf{k g ~ m} \mathbf{~ m}^{-\mathbf{3}}\right)\end{array}$ & Tank & $\begin{array}{l}\text { MIB } \\
(\mathbf{n g ~ k g}\end{array}$ & $\begin{array}{l}\text { Geosmin } \\
\mathbf{( n g ~ k g}^{-\mathbf{1}} \mathbf{)}\end{array}$ \\
\hline 1.4 & $\mathrm{R} 2$ & $20.2 \pm 4.4$ & $289.6 \pm 51.0$ \\
1.4 & $\mathrm{R} 6$ & $23.4 \pm 3.5$ & $51.0 \pm 8.3$ \\
1.4 & $\mathrm{R} 9$ & $12.0 \pm 2.0$ & $29.4 \pm 2.8$ \\
1.8 & $\mathrm{R} 1$ & $84.2 \pm 6.5$ & $33.8 \pm 2.5$ \\
1.8 & $\mathrm{R} 7$ & $27.0 \pm 3.2$ & $24.8 \pm 3.9$ \\
2.3 & $\mathrm{R} 4$ & $128.8 \pm 15.7$ & $98.0 \pm 9.9$ \\
2.3 & $\mathrm{R} 5$ & $21.4 \pm 1.4$ & $38.4 \pm 5.0$ \\
2.3 & R8 & $19.6 \pm 0.5$ & $121.4 \pm 9.2$ \\
\hline
\end{tabular}

*Each mean was obtained from the analysis of fillets from 5 separate catfish per tank and with the steam distillate from each fillet analyzed in triplicate.

TSS concentrations in our study may have affected FCR, but the true cause of the high FCR is unknown.

One result of the high feed rates used in this study was the linear increase in TSS with cumulative feed addition. Total suspended solids intentionally were allowed to accumulate to determine the maximum concentration that would be achieved and if feed consumption is impacted. Maximum TSS of 2100 and $1937 \mathrm{mg} \mathrm{L}^{-1}$ was observed in two replicate $\mathrm{HI}$ treatment tanks and $1749 \mathrm{mg}$ $\mathrm{L}^{-1}$ in one MED tank. These concentrations were higher than the 895-1063 $\mathrm{mg} \mathrm{L}^{-1}$ TSS reported by Schrader et al. (2011) and the 600-700 $\mathrm{mg} \mathrm{L}^{-1}$ TSS estimated from Green (2010) based on the TSS-SS relationship for this study. No water exchange or solids management was practised in any of these studies. High TSS concentrations (498-1095 $\mathrm{mg} \mathrm{L}^{-1}$ ) were reported for BFT tanks used to rear $L$. vannamei where cumulative feed addition averaged $6.6 \mathrm{~kg} \mathrm{~m}^{-3}$ and solids management was not practised (Ray, Lewis, Browdy \& Leffler 2010). In the present experiment, some fish mortality occurred in the HI treatment tank with the highest TSS concentration, and fish in the HI and MED treatment tanks with the highest TSS concentrations exhibited abnormal behaviour (swimming at the surface), but continued to eat.

High TSS concentrations in all treatments appeared to affect catfish feed consumption, the exact mechanism of which remains unknown. Results of the piecewise regression analysis of daily feed consumption (weekly mean) on TSS concentration showed a clear breakpoint from increasing to stable feed consumption with increasing TSS. Breakpoints occurred between mid-July to midAugust, well before decreasing water temperatures would limit growth. The reason for the significantly higher breakpoint for the HI treatment remains unclear, although competitive interactions during feeding may have allowed fish in the HI treatment to tolerate a higher TSS concentration.

We interpret the breakpoint to represent the negative impact of increasing TSS on further increases in feed consumption. Data used for this analysis were restricted to water temperatures above $25^{\circ} \mathrm{C}$ (except for the first 2-3 weeks when water temperatures ranged from 20 to $25^{\circ} \mathrm{C}$ ), so fish growth would not be temperature limited. Although fish were not sampled to measure growth during the experiment, our assumption of continued fish growth during the time encompassed by the dataset is reasonable. If fish growth had ceased, then feed consumption would have decreased to maintenance levels, which is unsupported by our data. The decrease in feed consumption on a per cent biomass basis as the fish grew (and biomass increased) is another possible explanation, but the two values would have to be in approximate equilibrium to be consistent with our results. Data for channel catfish grown in ponds show no relationship $(P=0.299)$ between estimated feed consumption (\% biomass basis) and mean individual weight over the $100-180 \mathrm{~g}$ fish $^{-1}$ size range, whereas fish growth over this size range exhibited a strong positive linear relationship ( $R^{2}=0.911$; B. Green, unpublished data). That TSS concentration in a BFT system impacts feeding negatively is supported by Ray, Lewis et al. (2010) who showed that L. vannamei yield was significantly greater and FCR was significantly lower when solids removal reduced TSS from 498 $-1095 \mathrm{mg} \mathrm{L}^{-1}$ to $231-616 \mathrm{mg} \mathrm{L}^{-1}$.

Based on our results, further increases in daily feed consumption by channel catfish are not expected once TSS exceeds $564-853 \mathrm{mg} \mathrm{L}^{-1}$. In practical terms, TSS concentration in a BFT system should be managed at a level well below that where feed consumption will be impacted. Targeting TSS concentrations that are $50 \%$ of the calculated breakpoint range, i.e. $282-427 \mathrm{mg} \mathrm{L}^{-1} \mathrm{TSS}$, should allow an adequate operating margin and is consistent with the results of Ray, Lewis et al. (2010).

Nitrogen and phosphorus inputs as feed via fish excretion were high during this study. Dissolved 
inorganic nitrogen dynamics in tanks (data not shown) were consistent with those reported for a BFT system in which nitrification is a dominant process (Green 2010; Ray, Lewis et al. 2010). Initial spikes in TAN concentration were followed by a transient increase in $\mathrm{NO}_{2}-\mathrm{N}$ concentration, followed beginning in early June by continuously increasing $\mathrm{NO}_{3}-\mathrm{N}$ concentration. The increasing $\mathrm{NO}_{3}-\mathrm{N}$ concentration is interpreted as nitrification. The strong positive correlation between $\mathrm{NO}_{3}-\mathrm{N}$ and solids (TSS and SS) indicates that nitrifying bacteria likely colonized biofloc particles. Chlorophyll a concentrations increased to greater than $500 \mathrm{mg} \mathrm{m}^{-3}$ by late April and remained high in all treatment tanks throughout the experiment (data not shown). Treatment means in this study were similar to those reported by Green (2010), but less than those reported by Schrader et al. (2011). In general, chlorophyll a concentration increases with increasing feed input (Boyd \& Tucker 1998) and both are positively related in channel catfish BFT systems (Green 2010; Schrader et al. 2011). The early and rapid increase to sustained high chlorophyll a concentrations in tanks in this study likely explains the ambiguous correlations between chlorophyll $a$ and feed input among treatments. Algal uptake (Hargreaves \& Tucker 1996; Hargreaves 2006) and nitrification acted to keep TAN and $\mathrm{NO}_{2}-\mathrm{N}$ concentrations in this study at low levels despite the high feed rates used.

Phytoplankton population composition and abundance went through the same three distinct periods in all treatments in this study. During period 1, colonial green algae (division Chlorophyta) and pennate diatoms (division Bacillariophyta) were the dominant phytoplankton groups in all tanks. Total phytoplankton numbers decreased to their minimums during period 2 , which appeared to be the transition period from a planktonic algae-dominated system and to a biofloc-dominated system. Chlorophytes and euglenoids (division Euglenophyta) disappeared from all tanks during period 2, whereas J. subtilissimum increased in abundance. It was during period 2 that solids (settleable and TSS) concentrations, i.e. biofloc particles, began to increase. During period 3, phytoplankton abundance increased to levels intermediate between periods 1 and 2, and populations in all tanks were dominated by J. subtilissimum and diatoms (centric and pennate), which were associated with the biofloc particles. Tempo- ral phytoplankton population dynamics are varied in BFT systems. The strong positive correlations observed between planktonic algal groups and the negative correlations between solids and planktonic algal groups are consistent with our division of phytoplankton population dynamics into three periods. Similarly consistent are the strong positive correlations observed between cyanobacteria trichomes and diatoms and between each of these groups and solids. Schrader et al. (2011) reported a similar periodicity in phytoplankton population dynamics for some channel catfish BFT tanks, but population composition and abundance differed from results in this study. In other previous studies, chlorophytes and cyanobacteria were the dominant groups and diatoms comprised only a fraction of the phytoplankton population in a brackishwater (Ray, Seaborn et al. 2010) and a marine (Vinatea et al. 2010) BFT system.

The decrease in the number of phytoplankton genera/groups with the progression from period 1 to period 3 comports with the general observation that species diversity usually will be lower as available nutrient concentrations increase (Reynolds 1984). While we did not identify most phytoplankton to species and thus cannot calculate a diversity index, our results are consistent with the above general observation. This is in contrast to Schrader et al. (2011), who reported no clear pattern of reduced phytoplankton population diversity with increased nutrient input.

Two genera of cyanobacteria (Planktothrix and Pseudanabaena) commonly associated with noxious algal blooms were identified in tanks, primarily during period 1 in this study. Neither $P$. agardhii nor Pseudanabaena sp. comprised greater than $1.75 \%$ of the phytoplankton population and generally was observed only on 1-2 sampling dates. Continuous diffused air aeration results in turbulent mixing of the water in the biofloc tanks. Turbulent mixing in natural water bodies exposes phytoplankton to variable light and nutrient gradients that can inhibit growth, and in cases of extreme turbulence can result in cyanobacteria cell and filament damage, and rapid death (Reynolds 1984; Paerl \& Tucker 1995). Nutrients are not limiting in BFT tanks, but phytoplankton are exposed to continuously varying light regimes as a result of this turbulent mixing, which favours the faster growing diatoms and chlorophytes over cyanobacterial bloom genera due to the loss of the competitive advantage provided by cell buoyancy 
regulation, a physiological mechanism unique to bloom-forming cyanobacteria (Reynolds 1984; Paerl \& Tucker 1995).

Concentrations of MIB and geosmin in tank water in this study varied among sample dates, were low in the June through August samples and attained their highest concentrations in the September or October samples. The maximum concentrations of MIB and geosmin in water measured in this study were substantially lower than those observed in catfish ponds in the south-eastern United States, where concentrations of MIB and geosmin in pond water can exceed $700 \mathrm{ng} \mathrm{L}^{-1}$ and $2000 \mathrm{ng} \mathrm{L}^{-1}$ respectively (Schrader \& Blevins 1993; Zimba \& Grimm 2003; Schrader \& Dennis 2005). None of the phytoplankton observed in tanks in this study, with the exception of Pseudanabaena sp., have been identified conclusively as producers of MIB or geosmin. The presence of Pseudanabaena sp. in most tanks on the 17 May and 1 June sample dates was coincident with the $18 \mathrm{ng} \mathrm{L}^{-1}$ mean MIB concentration in the 6 June water samples. However, Pseudanabaena sp. was absent when the higher MIB concentrations were measured later in the study. As Pseudanabaena sp. was not isolated for subsequent confirmation of MIB or geosmin production, the relative contribution, if any, to MIB or geosmin presence in the tanks is unknown. Most correlations in this study between MIB and geosmin concentrations in water and other variables were detected for the HI and LO treatments; the loss of one replicate may explain the absence of correlations in the MED treatment. The positive correlations of MIB or geosmin with TSS may indicate that the biofloc provided a good substrate for actinomycete colonization. There was a distinct lack of correlation between the presence of MIB and N. asteroides, e.g. N. asteroides was isolated from a tank water sample in which no MIB was detected or vice versa. Subsequently, the contribution of $N$. asteroides to MIB presence in the tanks is considered to be relatively minor, if any. The positive correlations between MIB or geosmin and diatoms or cyanobacteria likely were an artefact of the analysis because these phytoplankton also were positively correlated with TSS. Interestingly, MIB and cumulative feed addition were not correlated in this study, unlike the results reported by Schrader et al. (2011). However, this may have been due to the smaller dataset for MIB and geosmin concentrations in this study compared with Schrader et al. (2011) who collected samples on a biweekly basis starting in May. We did find a strong positive correlation between TSS and cumulative feed addition in all treatments.

All catfish fillets had analytically detectable levels $\left(\geq 1 \mathrm{ng} \mathrm{kg}^{-1}\right.$ ) of MIB and geosmin. Similar to Schrader et al. (2011), the highest levels of MIB and geosmin were measured in fish from tanks that did not have the highest concentrations of MIB and geosmin in the water. Previous research determined that trained catfish processing plant flavour testers possess sensory threshold detection levels of $100-200 \mathrm{ng} \mathrm{kg}^{-1}$ for MIB and 250$500 \mathrm{ng} \mathrm{kg}^{-1}$ for geosmin (Grimm, Lloyd \& Zimba 2004). Based on those guidelines, only fish from the R2 and R4 treatment tanks had geosmin and $\mathrm{MIB}$, respectively, in their flesh at sensory detectable levels, which might result in the classification as off-flavour, although not necessarily as severe or objectionable off-flavour, as by trained flavour testers. This low incidence of off-flavour fish is consistent with Schrader et al. (2011).

In summary, stocker channel catfish were produced using the BFT culture system. Additional research is needed on stocking rates and feed management to optimize the production of a 110-120-g stocker catfish. Planktonic algae dominated the phytoplankton communities in tanks initially, decreased to low levels and then disappeared as the biofloc developed, and were replaced by J. subtilissimum and diatoms (centric and pennate) that were associated closely with biofloc particles. High rates of feed application were possible because algal uptake and bacterial transformation of excreted nitrogen limited the accumulation of TAN. However, high rates of feeding resulted in accumulation of TSS, which can attain levels that appeared to impact negatively on feed consumption by fish. Thus, optimal TSS concentrations must be determined and strategies implemented to manage TSS. The off-flavour compounds MIB and geosmin were detected in tank waters at levels and for durations that were less than for catfish production ponds. Most of the sampled catfish did bioaccumulate MIB and geosmin, but at concentrations below sensory threshold detection levels. Although the frequency of occurrence and intensity of off-flavour in stockersize channel catfish is largely irrelevant, it is relevant to the BFT production system. This study further supports our previous observations that episodes and intensity of MIB- and geosmin-induced off-flavour in channel catfish are substantially lower than for pond-reared catfish. Additional research is required to determine the microbial sources 
responsible for geosmin and MIB production in the BFT tanks and to further investigate the effects of high feeding rates on geosmin and MIB concentrations in the fillets of catfish cultured in BFT tanks.

\section{Acknowledgments}

We thank Dr Kathy Yeater for her assistance with and informative discussion of PROC GLIMMIX. The technical assistance of Greg O’Neal, Matt McEntire, Dewayne Harries and Phaedra Page is greatly appreciated. This study was funded by the USDA/ ARS under project number 6225-31630-006-00D. No sources of funding external to any author institution were used for this study. None of the authors have any conflict of interest. Mention of trade names or commercial products in this article is solely for the purpose of providing specific information and does not imply recommendation or endorsement by the US Department of Agriculture. USDA is an equal opportunity provider and employer.

\section{References}

Avnimelech Y. (1999) Carbon/nitrogen ratios as a control element in aquaculture systems. Aquaculture 176, 227-235.

Avnimelech Y., Diab S., Kochba M. \& Mokady S. (1992) Control and utilization of inorganic nitrogen in fish culture ponds. Aquaculture and Fisheries Management 23, 421-430.

Box G.E.P. \& Cox D.R. (1964) An analysis of transformations. Journal of the Royal Statistical Society B 26, 211252.

Boyd C.E. \& Tucker C.S. (1998) Pond Aquaculture Water Quality Management. Kluwer Academic Publishers, Boston, MA, USA.

Cocke E.C. (1967) The Myxophyceae of North Carolina. Edwards Brothers, Ann Arbor, MI, USA.

D'Abramo L.R., Steeby J.A., Hanson T.R. \& Gerard P.D. (2006) Evaluation of a fingerling-to-stocker phase as part of a new production strategy for the commercial farming of channel catfish. North American Journal of Aquaculture 69, 22-35.

D’Abramo L.R., Hanson T.R. \& Steeby J.A. (2008) Production and associated economics of channel catfish fed different practical diets in the fingerling-stocker phase of culture. North American Journal of Aquaculture 70, 154-161.

Desikachary T.V. (1959) Cyanophyta. Indian Council of Agricultural Research, New Delhi, India.

Eaton A.D., Clesceri L.S., Rice E.W. \& Greenberg A.E. (2005) Standard Methods for the Examination of Water and Wastewater (21st edn). American Public Health Association, Washington, DC, USA.

Genfa Z. \& Dasgupta P.K. (1989) Fluorometric measurement of aqueous ammonia ion in a flow injection system. Analytical Chemistry 61, 408-412.

Green B.W. (2010) Effect of channel catfish stocking rate on yield and water quality in an intensive, mixed suspended-growth production system. North American Journal of Aquaculture 72, 97-106.

Green B.W. \& Engle C.R. (2004) Growth of stocker channel catfish to large market size in single-batch culture. Journal of the World Aquaculture Society $\mathbf{3 5}$, $25-32$.

Green B.W., Perschbacher P., Ludwig G. \& Duke S.E. (2010) Threadfin shad impacts phytoplankton and zooplankton community structures in channel catfish ponds. Aquaculture Research 41, e524-e536.

Grimm C.C., Lloyd S. \& Zimba P.V. (2004) Instrumental versus sensory detection of off-flavors in farm-raised channel catfish. Aquaculture 236, 309-319.

Hargreaves J.A. (2006) Photosynthetic suspended-growth systems in aquaculture. Aquacultural Engineering 34, 344-363.

Hargreaves J.A. \& Tucker C.S. (1996) Evidence for control of water quality in channel catfish Ictalurus punctatus ponds by phytoplankton biomass and sediment oxygenation. Journal of the World Aquaculture Society 27, 21-29.

Lloyd S.W. \& Grimm C.C. (1999) Analysis of 2-methylisoborneol and geosmin in catfish by microwave distillation-solid-phase microextraction. Journal of Agricultural and Food Chemistry 47, 164-169.

Lloyd S.W. \& Tucker C.S. (1988) Comparison of three solvent systems for extraction of chlorophyll a from fish pond phytoplankton communities. Journal of the World Aquaculture Society 19, 36-40.

Lloyd S.W., Lea J.M., Zimba P.V. \& Grimm C.C. (1998) Rapid analysis of geosmin and 2-methylisoborneol in water using solid phase micro extraction procedures. Water Research 32, 2140-2146.

Paerl H.W. \& Tucker C.S. (1995) Ecology of blue-green algae in aquaculture ponds. Journal of the World Aquaculture Society 26, 109-131.

Pomerleau S. \& Engle C.R. (2003) Production of stockersize channel catfish: Effect of stocking density on production characteristics, costs, and economic risk. North American Journal of Aquaculture 65, 112-119.

Pomerleau S. \& Engle C.R. (2005) The effect of on-farm production of various sizes of stocker caffish Ictalurus punctatus on farm profitability. Journal of the World Aquaculture Society 36, 291-301.

Ray A.J., Seaborn G., Leffler J.W., Wilde S.B., Lawson A. \& Browdy C.L. (2010) Characterization of microbial communities in minimal-exchange, intensive aquaculture systems and the effects of suspended solids management. Aquaculture 310, 130-138. 
Ray A.J., Lewis B.L., Browdy C.L. \& Leffler J.W. (2010) Suspended solids removal to improve shrimp (Litopenaeus vannamei) production and an evaluation of a plant-based feed in minimal-exchange, superintensive culture systems. Aquaculture 299, 89-98.

Reynolds C.S. (1984) The Ecology of Freshwater Phytoplankton. Cambridge University Press, Cambridge, England.

Ryan S.E. \& Porth L.S. (2007) A Tutorial on the Piecewise Regression Approach Applied to Bedload Transport Data. General Technical Report, RMRS-GTR-189. US Department of Agriculture, Forest Service, Rocky Mountain Research Station, Fort Collins, CO, USA.

Schrader K.K. \& Blevins W.T. (1993) Geosmin-producing species of Streptomyces and Lyngbya from aquaculture ponds. Canadian Journal of Microbiology 39, 834-840.

Schrader K.K. \& Dennis M.E. (2005) Cyanobacteria and earthy/musty compounds found in commercial catfish (Ictalurus punctatus) ponds in the Mississippi Delta and Mississippi-Alabama Blackland Prairie. Water Research 39, 2807-2814.

Schrader K.K., Nanayakkara N.P.D., Tucker C.S., Rimando A.M., Ganzera M. \& Schaneberg B.T. (2003) Novel derivatives of 9,10-anthraquinone are selective algicides against the musty-odor cyanobacterium Oscillatoria perornata. Applied and Environmental Microbiology 69 , 5319-5327.

Schrader K.K., Davidson J.W., Rimando A.M. \& Summerfelt S.T. (2010) Evaluation of ozonation on levels of the off-flavor compounds geosmin and 2-methylisoborneol in water and rainbow trout Oncorhynchus mykiss from recirculating aquaculture systems. Aquacultural Engineering 43, 46-50.
Schrader K.K., Green B.W. \& Perschbacher P.W. (2011) Development of phytoplankton communities and common off-flavors in a biofloc technology system used for the culture of channel catfish (Ictalurus punctatus). Aquacultural Engineering 45, 118-126.

Smith D.W. (1988) Phytoplankton and catfish culture: A review. Aquaculture 74, 167-189.

Tucker C.S. (2000) Off-flavor in aquaculture. Reviews in Fisheries Science 8, 45-88.

Tucker C.S. \& Lloyd S.W. (1984) Phytoplankton communities in channel catfish ponds. Hydrobiologia 112, 137-141.

Tucker C.S. \& van der Ploeg M. (1993) Seasonal changes in water quality in commercial channel catfish ponds in Mississippi. Journal of the World Aquaculture Society 24, 473-481.

United States Department of Agriculture (USDA) (2010) Catfish 2010 Part II: Health and Production Practices for Foodsize Catfish in the United States, 2009. USDAAPHIS-VS, CEAH, \#595.0611. National Animal Health Monitoring System, Fort Collins, CO, USA.

Vinatea L., Galvez A.O., Browdy C.L., Stokes A., Venero J., Haveman J., Lewis B.L., Lawson A., Shuler A. \& Leffler J.W. (2010) Photosynthesis, water respiration and growth performance of Litopenaeus vannamei in a superintensive raceway culture with zero water exchange: Interaction of water quality variables. Aquacultural Engineering 42, 17-24.

Zimba P.V. \& Grimm C.C. (2003) A synoptic survey of musty/muddy odor metabolites and microcystin toxin occurrence and concentration in southeastern USA channel catfish (Ictalurus punctatus Ralfinesque) production ponds. Aquaculture 218, 81-87. 